\title{
HUBUNGAN JARAK TEMPAT TINGGAL, ALAT TRANSPORTASI, SERTA PERSEPSI PASIEN TERHADAP KETERLAMBATAN PASIEN KE INSTALASI GAWAT DARURAT PADA PASIEN PENYAKIT JANTUNG KORONER
}

\author{
Iis Siti Sholihah ${ }^{1}$, Nandar Wirawan ${ }^{2}$, Yanto Rohyadi ${ }^{3}$, M.Iqbal Angga Kusuma ${ }^{4}$ \\ ${ }^{1,3}$ STIKes Sebelas April Sumedang \\ ${ }^{2}$ RSUD Sumedang \\ ${ }^{4}$ STIKes Jenderal Achmad Yani Cimahi \\ nandarwirawan83@gmail.com
}

\begin{abstract}
ABSTRAK
Penyakit Jantung Koroner (PJK) merupakan penyakit dengan proporsi angka kematian tertinggi. PJK menduduki tingkat kedua dari 10 besar diagnosis. PJK membutuhkan penatalaksanaan yang cepat dan tepat dalam masa golden period selama 90 menit, namun seringkali terjadi keterlambantan kedatangan pasien ke Instalasi Gawat Darurat (IGD) yang mengakibatkan kematian. Penelitian ini bertujuan mengetahui faktor-faktor yang melatarbelakangi keterlambatan pasien ke IGD pada PJK di RSUD Sumedang. Penelitian ini menggunakan Pendekatan Cross Sectional dengan besar sampel sebanyak 36 responden (accidental sampling). Data dikumpulkan dengan menggunakan kuesioner faktor keterlambatan pasien PJK datang ke IGD. Data dianalisis dengan Metode Uji Chi Square. Hasil analisis terdapat hubungan jarak tempat tinggal $(p$-value $=0,045)$, penggunaan transportasi ( $p$-value $=0,024)$, perilaku mencari pelayanan kesehatan $(p$-value $=0,001)$, persepsi pasien $(p$-value $=0,012)$ dengan keterlambatan pasien datang ke IGD dengan keluhan nyeri dada pada PJK. Jarak tempat tinggal, penggunaan transportasi, pencarian pelayanan kesehatan dan persepri pasien memiliki hubungan yang bermakna dengan keterlambatan pasien datang ke IGD pada pasien penyakit jantung koroner. Diharapkan pelayanan kesehatan memberikan edukasi terhadap pasien yang berisiko mengalami nyeri dada atau serangan jantung seperti pada pasien dengan riwayat penyakit hipertensi, diabetes melitus, kolesterol, strok sehingga jika terdapat tanda gejala nyeri dada pasien dapat langsung mengenali, mengatasi kegawatan di rumah dan cepat mencari pelayanan kesehatan.
\end{abstract}

Kata kunci : keterlambatan pre-hospital, nyeri dada, penyakit jantung koroner

\section{RELATIONSHIP OF DISTANCE OF RESIDENCE, MEANS OF TRANSPORTATION, AND PATIENT'S PERCEPTION OF PATIENT'S DELAY TO EMERGENCY INSTALLATION IN CORONARY HEART DISEASE PATIENTS}

\section{ABSTRACT}

Coronary Heart Disease (CHD) is a disease with the highest proportion of deaths, he second level of the top 10 diagnoses. CHD requires fast and appropriate management during the golden period of 90 minutes, but there is often a delay in the patient's arrival to the ER which results in death. This study aims to determine the factors behind the delay of patients to the ER for CHD at Sumedang Hospital. This study used a cross sectional approach with a sample size of 36 respondents (Accidental Sampling). Data were collected using open and closed questionnaires factors of delay in CHD patients coming to the ED. Data were analyzed by Chi Square test method. The results of the 
analysis showed that there was a relationship between residence distance $(p=0.045)$, use of transportation $(p=0.024)$, behavior seeking health services $(p=0.001)$, patient perception $(p=0.012)$ with patient delays in coming to the ER with complaints of chest pain in CHD. There is a significant relationship between the distance of the patient's residence, the behavior of seeking health services, the use of transportation and the perception of the patient with the delay of the patient coming to the ER in patients with coronary heart disease. It is expected that health services provide education to patients who are at risk of experiencing chest pain or heart attack such as in patients with a history of hypertension, diabetes mellitus, cholesterol, stroke so that if there are signs of chest pain the patient can immediately recognize, deal with emergencies at home and quickly seek health services.

Keywords: chest pain, coronary heart disease, pre-hospital delay

\section{PENDAHULUAN}

Berdasarkan data World Health
Organization (WHO) tahun 2013, 56 juta
kematian di seluruh dunia 38 juta diantaranya disebabkan oleh Penyakit Tidak Menular (PTM) dan proporsi penyebab utama kematian PTM pada tahun 2013 itu diantaranya : penyakit kardiovaskular (37\%), kanker (27\%), penyakit pernafasan $(8 \%)$, dan diabetes $(4 \%)$. Kematian karena penyakit kardiovaskular tersebut 7,4 juta disebabkan oleh Penyakit Jantung Koroner (PJK) Liu, (2014). Penyebab kematian pada penyakit jantung koroner itu diantaranya adalah faktor usia produktif yang dipengaruhi oleh pola makan, gaya hidup, aktivitas fisik yang kurang, merokok, jenis kelamin, jarak dan waktu tempuh ke sarana pelayanan kesehatan. PJK membutuhkan penatalaksanaan yang cepat dan tepat, tetapi yang sering terjadi adalah waktu keterlambatan pre-hospital yang panjang. Dalam penelitian Saberi et al (2014) beberapa faktor penyebab keterlambatan datang ke rumah sakit disebabkan oleh jenis kelamin pasien, usia, tingkat pendidikan, tempat tinggal/jarak, kesadaran akan gejala, kualitas nyeri, lokasi nyeri, jenis nyeri, dan waktu rasa nyeri, riwayat gangguan jantung, jenis transportasi, dan pasien yang mendapatkan rujukan sebelumnya.

\section{American College of Cardiology} Foundation dan American Hearth Association
(ACCF/AHA) (2013) menyatakan bahwa standar waktu saat munculnya gejala hingga dimulai untuk terapi perfusi adalah 120 menit, dan waktu yang direkomendasikan (Golden Period) 30 menit atau kurang untuk merawat pasien. Maknanya pasien harus dirawat di rumah sakit dalam waktu 90 menit setelah timbulnya gejala (O’Gara et al., 2013).

Berdasarkan Bank Data Sub.Bag Program RSUD Sumedang pada bulan JanuariDesember tahun 2017 didapatkan hasil bahwa PJK menduduki tingkat ketiga dari data diagnosis 10 besar di Instalasi Gawat Darurat (IGD) dengan jumlah kematian PJK sebanyak 7 orang. Adapun pada bulan Januari-April tahun 2018 pasien yang didiagnosis PJK sebanyak 36 pasien dan menduduki tingkat kedua dari data diagnosis 10 besar di IGD. Pasien PJK yang datang ke RSUD Sumedang kebanyakan terlambat datang ke rumah sakit. Hal itu akan meningkatkan angka kesakitan dan kematian. Penelitian ini bertujuan untuk mengetahui faktor jarak tempat tinggal, penggunaan transportasi, perilaku pencarian pelayanan kesehatan, persepsi pasien yang berhubungan dengan keterlambatan pasien datang ke IGD disertai keluhan nyeri dada pada PJK. Diharapkan penelitian ini dapat dijadikan Evidence Based Practice bahwa semakin cepat pasien dengan keluhan nyeri dada yang didiagnosis PJK mendapatkan pelayanan 
kesehatan maka akan mendapatkan hasil yang semakin baik.

\section{METODOLOGI}

Jenis penelitian yang digunakan adalah penelitian kuantitatif dengan desain penelitian deskriptifkorelasi. Desain penelitian ini dilakukan dengan Pendekatan Cross Sectional. Variabel independen dalam penelitian ini yaitu jarak, penggunaan transportasi, perilaku pencarian pelayanan kesehatan, dan persepsi pasien, sedangkan yang menjadi variabel dependen dalam penelitian ini keterlambatan datang ke IGD. Populasi dalam penelitian ini yaitu pasien yang datang ke IGD RSUD Sumedang dengan keluhan nyeri dada yang didiagnosis PJK dengan populasi berjumlah 36 orang berdasarkan data yang datang ke IGD dengan diagnosis PJK selama bulan Januari-April. Pengambilan sampel dalam penelitian ini dengan menggunakan total sampel semua populasi dijadikan sampel yang berjumlah 36 orang dengan Teknik Accidental Sampling.
Alat yang digunakan dalam penelitian adalah kuesioner keterlambatan pasien PJK ke IGD terdiri dari 19 pertanyaan menggunakan skala rasio, nominal, dan likert dengan uji validitas dan reabilitas menggunakan uji konten berdasarkan penelitian (Saberi et al., 2014) yang terdiri dari 2 bagian, bagian pertama terdapat pertanyaan tentang demografi (usia, tingkat pendidikan, status pekerjaan, status perkawinan, kebiasaan merokok, jenis asuransi, lokasi tempat tinggal, lokasi, dan waktu gejala pertama, dan gejala pertama yang dirasakan, dan riwayat penyakit. Bagian kedua terdapat waktu dari merasakan gejala sampai ke rumah sakit, jarak antara tempat tinggal dan rumah sakit, transportasi yang digunakan untuk datang ke rumah sakit, mengetahui atau tidaknya tentang gejala serangan jantung, mengetahui atau tidaknya nomor telepon layanan medis darurat, dan pertanyaan untuk perilaku pencarian pelayanan kesehatan dan persepsi pasien, analisis bivariat dilakukan dengan Metode Uji Chi Square.

\section{HASIL}

Tabel 1. Hubungan Jarak Tempat Tinggal, Penggunaan Transportasi, Perilaku Mencari Pelayanan Kesehatan dengan Keterlambatan Pasien Datang ke IGD disertai Keluhan Nyeri Dada pada Penyakit Jantung Koroner di RSUD Sumedang Tahun 2018

\begin{tabular}{|c|c|c|c|c|c|c|c|}
\hline \multirow{3}{*}{ Kriteria } & \multicolumn{4}{|c|}{ Keterlambatan } & & & \multirow{3}{*}{ p-value } \\
\hline & \multicolumn{2}{|c|}{$\begin{array}{l}\text { Terlambat } \\
\text { Datang }\end{array}$} & \multicolumn{2}{|c|}{$\begin{array}{c}\text { Tidak Terlambat } \\
\text { Datang }\end{array}$} & \multicolumn{2}{|c|}{ Total } & \\
\hline & f & $\%$ & f & $\%$ & f & $\%$ & \\
\hline \multicolumn{8}{|l|}{ Jarak Tempat Tinggal } \\
\hline Sedang & 2 & 40,0 & 3 & 60,0 & 5 & 100 & \multirow{3}{*}{0,045} \\
\hline Cukup Jauh & 11 & 84,6 & 2 & 15,4 & 13 & 100 & \\
\hline Jauh & 16 & 88,9 & 2 & 11,1 & 18 & 100 & \\
\hline \multicolumn{8}{|c|}{ Penggunaan Transportasi } \\
\hline Ambulance & 1 & 33,3 & 2 & 66,7 & 3 & 100 & \multirow{3}{*}{0,024} \\
\hline Kendaraan Pribadi & 10 & 71,4 & 4 & 28,6 & 14 & 100 & \\
\hline Kendaraan Umum & 18 & 94,7 & 1 & 5,3 & 19 & 100 & \\
\hline
\end{tabular}




\begin{tabular}{|c|c|c|c|c|c|c|c|}
\hline \multirow{3}{*}{ Kriteria } & \multicolumn{4}{|c|}{ Keterlambatan } & & & \multirow{3}{*}{ p-value } \\
\hline & \multicolumn{2}{|c|}{$\begin{array}{c}\text { Terlambat } \\
\text { Datang }\end{array}$} & \multicolumn{2}{|c|}{$\begin{array}{c}\text { Tidak Terlambat } \\
\text { Datang }\end{array}$} & \multicolumn{2}{|c|}{ Total } & \\
\hline & $\mathbf{f}$ & $\%$ & f & $\%$ & $\mathbf{f}$ & $\%$ & \\
\hline \multicolumn{8}{|l|}{ Perilaku } \\
\hline Baik & 1 & 20,0 & 4 & 80,0 & 5 & 100 & \multirow{3}{*}{0,001} \\
\hline Cukup & 7 & 87,5 & 1 & 12,5 & 8 & 100 & \\
\hline Kurang & 21 & 91,3 & 2 & 8,7 & 23 & 100 & \\
\hline
\end{tabular}

\section{PEMBAHASAN}

Hasil penelitian pada pasien yang mengeluh nyeri dada tidak dapat menjangkau tempat pelayanan kesehatan terdekat dikarenakan jarak yang jauh yang tidak dapat dijangkau dengan jalan kaki, transportasi juga kurang memadai dikarenakan tidak mempunyai kendaraan pribadi, jika menggunakan kendaraan umum harus menunggu dulu dikarenakan tidak ada kendaraan umum yang melewati depan rumah. Hal ini rmembuktikan bahwa jarak salah satu faktor yang dapat menyebabkan keterlambatan pada pasien yang mengeluh nyeri dada pada penyakit jantung koroner di RSUD Kabupaten Sumedang.

Suharyono \& Amien, (2013) menjelaskan bahwa jarak merupakan salah satu faktor yang diukur berdasarkan jauh dekatnya dari tempat tinggal sampaimendapatkanpelayanankesehatan. Hasil penelitian pasien yang mengeluh nyeri dada kebanyakan pasien tidak mempunyai kendaraan pribadi di rumah dan waktu gejala yang memang kebanyakan dirasakan pada malam hari sehingga pasien mengalami kesulitan menuju rumah sakit, dan juga kebanyakan pasien tidak menggunakan ambulans disebabkan bahwa pasien merasa tidak mengalami sakit serius, selain itu pasien percaya bahwa menggunakan kendaraan pribadi akan lebih cepat sampai ke IGD dibandingkan apabila menggunakan ambulan.

Hal ini membuktikan bahwa penggunaan transportasi salah satu faktor yang dapat menyebabkan keterlambatan pada pasien yang mengeluh nyeri dada pada penyakit jantung coroner. Hal ini sesuai dengan penelitian Fares et al., (2014)emergency medicine has established itself and developed rapidly in the UAE. Large, well-equipped emergency departments (EDs sebagian besar pasien tidak mempunyai kendaraan pribadi, sehingga pasien dan keluarga mengalami kesulitan untuk pergi ke rumah sakit. Selain itu, apabila meminjam atau menunggu saudara yang lain membawa kendaraan akan memperlama waktu tiba di IGD. Penggunaan ambulans pun mengindikasikan bahwa pasien memahami bahwa PJK merupakan suatu kondisi kegawatdaruratan medis yang harus segera mendapat pertolongan yang tepat (O'Gara et al., 2013).

Perilaku pasien yang mengeluh nyeri dada pada penyakit jantung koroner untuk mencari pelayanan kesehatan dalam kategori kurang yang disebabkan oleh sebagian besar pasien memilih untuk pengobatan sendiri di rumah seperti diolesi minyak gosok, dipijit terlebih dahulu, ataupun memilih menuju pengobatan alternative, dukun, mantri terlebih dahulu sebelum ke IGD maka perilaku itu akan semakin memperlama waktu tiba di IGD (Irman et al., 2017b)then analyzed with univariate analysis and bivariate (Fisher test.

Hal ini sesuai dengan penelitian Saberi et al., (2014) mengemukakan bahwa di Indonesia, penyebab pasien tiba terlambat di IGD disebabkan oleh mayoritas penderita PJK mengobati diri sendiri seperti kompres, diolesi minyak gosok 
dan dipijit terlebih dahulu sebelum ke rumah sakit.

Pencarian pengobatan terlebih dahulu ke pusat pelayanan selain IGD, seperti menuju ke dokter praktek, memanggil perawat, ke dukun, pengobatan alternatif yang menyebabkan akan semakin lama waktu tiba di IGD. Penelitian ini juga sesuai dengan penelitian Irman et al., (2017)then analyzed with univariate analysis and bivariate (Fisher testbahwa mayoritas perilaku pencarian pelayanan kesehatan dengan menunda ke rumah sakit (76,2\%). Penanganan yang dilakukan sebelum ke rumah sakit terbanyak itu berbaring, beli obat dan obati diri sendiri.

Persepsi pasien untuk pencarian pelayanan kesehatan dalam kategori kurang, hal ini disebabkan oleh kebanyakan pasien berpresepsi bahwa nyeri akan hilang dengan sendirinya, mengabaikan nyeri, berpikiran bahwa itu nyeri dada biasa yang tidak perlu ditangani dengan cepat. Hal ini sesuai dengan teori dalam buku Notoatmodjo, (2005) yang memaparkan bahwa persepsi adalah pengalaman tentang objek, peristiwa, atau hubungan-hubungan yang didapatkan dengan menyimpulkan informasi dan menafsirkannya. Persepsi orang kebanyakan berharap gejala mereda secara spontan, menghubungkan gejala dengan masalah lain selain masalah jantung, dan mengabaikan gejala (Taghaddosi et al., 2010).

Pasien akan merespons dengan tepat saat onset gejala dirasakan McSweeney et al., (2007). Pasien yang mengeluh nyeri dada pada penyakit jantung koroner terlambat datang ke IGD disebabkan oleh waktu tunda dari gejala mulai dirasakan sampai di IGD $\geq 90$ menit, jarak yang jauh, transportasi yang tidak memadai, perilaku dan persepsi pasien dalam kategori kurang.

Keterlambatan prehospital pada dasarnya tergantung pada pasien serta kesiapan pertolongan prehospital. Keterlambatan prehospital dikaitkan dengan persepsi pasien tentang nyeri kardiak yang dirasakan. Pasien yang mempersepsikan penyakit jantung memiliki kemungkinan untuk segera mencari perawatan dalam waktu satu jam setelah onset gejala, berbeda dengan pasien yang mempersepsikan bukan penyakit jantung Mooney, (2014). Terdapat hubungan yang bermakna antara jarak dengan keterlambatan pasien datang ke IGD disertai keluhan nyeri dada pada penyakit jantung coroner. Beberapa faktor yaitu meskipun jarak tempat tinggal dengan rumah sakit tidak terlalu jauh tetapi kebanyakan menunda untuk pergi ke rumah sakit dengan beberapa alasan seperti responden berpikir nyeri yang dirasakan akan hilang dengan sendirinya, mengira nyeri dada itu nyeri dada biasa, melakukan perawatan sendiri sebelum ke rumah sakit.

Keterlambatan disebabkan oleh tidak dapat menjangkau tempat pelayanan kesehatan terdekat dengan berjalan kaki, transportasi kurang memadai dikarenakan tidak mempunyai kendaraan pribadi, jika menggunakan kendaraan umum harus menunggu dulu dikarenakan tidak ada kendaraan umum yang melewati depan rumah Mooney, (2014). Adapun pada responden yang tidak terlambat datang ke IGD yang disebabkan oleh tidak menunda untuk pergi ke pelayanan kesehatan begitu gejala dirasakan langsung dibawa ke rumah sakit dikarenakan sakitnya sudah tidak bisa tertahankan sudah ingin cepat ditangani agar sakitnya tidak bertambah parah jadi walaupun jarak jauh, dalam perjalanan menuju IGD tidak ada masalah seperti macet, dan juga disekitar tempat tinggalnya terdapat pelayanan kesehatan dari tempat itu langsung dengan cepat dirujuk ke IGD. Jarak ke pelayanan kesehatan yang mudah seperti perjalanan lancar tidak ada kemacetan, tidak ada masalah dalam perjalanan, alat transportasi yang dapat mempercepat sampai ke pelayanan seperti ambulans tidak akan terjadi keterlambatan prehospital.

Berdasarkan penelitian yang telah 
peneliti lakukan jarak tempat tinggal pasien ke IGD kebanyakan tergolong dalam kategori jauh. Hal ini sesuai dengan penelitian AdibHajbaghery \& Hoseinian, (2014) bahwa jarak tempat tinggal yang jauh ke rumah sakit adalah penyebab paling umum penundaan masuk rumah sakit (31,7\%). Analisis multivariat menunjukkan bahwa lokasi residensi dan jenis kendaraan transportasi dapat memprediksi secara signifikan waktu tunda pada pasien dengan AMI. Terdapat hubungan yang bermakna antara penggunaan transportasi dengan keterlambatan pasien datang ke IGD dengan keluhan nyeri dada pada penyakit jantung koroner, mayoritas pasien menggunakan kendaraan umum dan mayoritas tidak menggunakan ambulans dengan alasan pasien merasa gejala yang dirasakan tidak terlalu gawat atau tidak begitu serius, tidak mengetahui nomor layanan gawat darurat, tidak tersedianya ambulan desa di tempat tinggalnya dan belum tersedianya layanan gawat darurat medis. Selain itu, pasien serta keluarga harus menunggu beberapa saat untuk mendapatkan transportasi ke rumah sakit.

Hingga saat ini layanan gawat darurat medis di Indonesia hanya terdapat di beberapa kota besar seperti Jakarta, Surabaya, Makasar, Denpasar, Yogyakarta serta Palembang. Sehubungan dengan itu, sebagian besar pasien menggunakan berbagai macam transportasi seperti kendaraan umum, kendaraan pribadi maupun kendaraan yang dipinjam dari tetangga ataupun keluarga untuk menuju ke pelayanan kesehatan (Pitt \& Pusponegoro, 2005).

Penelitian oleh Thuresson et al., (2008) memaparkan bahwa, jenis transportasi terbukti berpengaruh terhadap waktu keterlambatan penanganan sebelum ke rumah sakit. Di Negaranegara berkembang seperti Libanon dan Brasil yang belum memiliki layanan gawat darurat medis memadai, dilaporkan hanya $3,1 \%$ pasien datang dengan ambulans. Selain itu, dilaporkan bahwa rata-rata waktu tiba pasien di IGD yaitu 2 jam 52 menit dan hanya 11,9\% pasien tiba di IGD kurang dari 120 menit.

Penelitian Irman et al., (2017a) yang memaparkan bahwa, mayoritas jenis transportasi yang digunakan ialah kendaraan umum. Penyebab lain keterlambatan datang ke IGD dikarenakan belum adanya layanan gawat darurat medis, mayoritas pasien dibawa ke IGD dengan kendaraan umum, akibatnya terjadinya waktu keterlambatan yang semakin memanjang Fares et al., (2011). Penyebab lainnya waktu keterlambatan penanganan sebelum masuk ke rumah sakit terbanyak yaitu tiba terlambat $(>120$ menit) sehingga kesimpulan dari penelitiannya bahwa ada hubungan jenis transportasi dengan waktu keterlambatan penanganan sebelum masuk ke rumah sakit pasien SKA di IGD RSUD dr. TC. Hillers Maumere. Penelitian ini juga sesuai dengan pendapat Fares et al., (2011) bahwa sebagian besar pasien tidak mempunyai kendaraan pribadi di rumah. Pasien mengalami kesulitan untuk pergi ke rumah sakit. Selain itu juga dengan meminjam atau menunggu saudara yang lain membawa kendaraan akan memperlama waktu tiba di IGD. Pengunaan ambulan juga mengindikasikan bahwa pasein memahami bahwa PJK merupakan suatu kondisi kegawatan medis yang harus segera mendapat pertolongan yang tepat Mooney, (2014). Perilaku pasien yang mengeluh nyeri dada pada penyakit jantung koroner untuk mencari pelayanan kesehatan dalam kategori kurang yang disebabkan oleh sebagian besar pasien memilih untuk pengobatan sendiri di rumah seperti diolesi minyak gosok, dipijit terlebih dahulu, ataupun memilih menuju pengobatan alternative, dukun, mantri terlebih dahulu sebelum ke IGD maka perilaku itu akan semakin memperlama waktu tiba di IGD.

Selain kendaraan, terdapat pula hubungan antara perilaku dengan keterlambatan pasien datang ke IGD dengan keluhan nyeri dada pada 
penyakit jantung coroner. Penanganan sebelum ke rumah sakit kebanyakan hanya berbaring, diolesi minyak gosok, dipijit terlebih dahulu, ataupun memilih menuju pengobatan alternatif, dukun, mantri memanggil perawat atau menuju dokter umum, dan pasien beranggapan bahwa mereka tidak memiliki keturunan penyakit jantung sehingga tidak langsung menuju pelayanan gawat darurat.

Hal ini sesuai dengan penelitian yang dilakukan oleh Farshidi et al., (2013) yang menyebutkan bahwa $34,3 \%$ pasien tiba terlambat di IGD disebabkan oleh upaya mengobati diri sendiri pada saat serangan nyeri dada, selain itu juga dijelaskan bahwa waktu keterlambatan sangat beresiko pada kematian. Kematian akibat pasien tiba terlambat mempunyai risiko sebesar 3 kali lebih besar dibandingkan dengan pasien yang tiba lebih awal di rumah sakit Irman et al., (2017a)then analyzed with univariate analysis and bivariate (Fisher test. Penelitian Taghaddosi et al., (2010) yang memaparkan bahwa pasien tiba terlambat di IGD dikarenakan setelah berobat ke dokter praktek, pasien pulang ke rumah selanjutnya ke rumah sakit, selain itu proses konsultasi dengan dokter juga memakan waktu yang lama.

Hal ini juga didukung penelitian yang dilakukan oleh Widyarani, (2014) membuktikan bahwa pengobatan tradisional seperti ke dukun atau kyai terbukti mempunyai rata-rata waktu tiba di IGD paling lama yaitu 24 jam 30 menit. Pengobatan ke dukun tidak hanya terjadi di Indonesia, hal ini juga terjadi di Lima Peru, hasil penelitian menunjukkan sebanyak $4,4 \%$ pasien ke dukun saat munculnya tanda gejala penyakit. Untuk mengurangi waktu keterlambatan, sangat diperlukan intervensi pendidikan individual yang berfokus identifikasi gejala tindakan yang tepat untuk dilakukan pada saat serangan penyakit.

Terdapat hubungan antara persepsi dengan keterlambatan pasien datang ke IGD dengan keluhan nyeri dada pada penyakit jantung coroner, pasien mempersepsikan bahwa nyeri dada yang dirasakan itu bukan penyakit jantung hanya sakit dada biasa, nyeri dada akan hilang dengan sendirinya, menganggap hanya kecapean, hanya didiamkan selama gejala dirasakan menganggap gejala yang dirasakan itu bukan penyakit yang serius.

Hal ini sesuai dengan pendapat McSweeney et al., (2007), penelitian sebelumnya dijelaskan bahwa kesalahan persepsi pasien terhadap keluhan penyakit menjadi penyebab pasien tiba terlambat. Selain itu juga disebabkan oleh masalah psikologis, dimana pasien tidak menerima bahwa mereka menderita SKA. Terbukti hasil penelitian yang dilakukan di RSUD dr. T.C. Hillers Maumere menunjukkan dari 43 orang penderita SKA sebanyak 28 orang (66,7\%) mempersepsikan bahwa sakit yang dialami adalah bukan penyakit jantung melainkan kecapean $(23,8 \%)$, sakit dada biasa $(26,2 \%)$, disantet orang $(9,5 \%)$ dan sakit lambung $(7,1 \%)$.

\section{SIMPULAN DAN SARAN}

Terdapat hubungan yang bermakna antara faktor jarak ( $p$-value $=0,0045$ penggunaan transportasi $(p$-value $=0,024$, perilaku pencarian pelayanan kesehatan $(p$-value $=0,001$, serta persepsi pasien ( $p$-value $=0,012$ dengan keterlambatan pasien datang ke IGD disertai keluhan nyeri dada pada penyakit jantung koroner di RSUD Kabupaten Sumedang Tahun 2018.

Hasil penelitian ini kiranya dapat dijadikan sebagai bahan acuan pembelajaran untuk pusat pelayanan kesehatan dalam berupaya melakukan penyampaian informasi atau memberikan edukasi terhadap pasien yang berisiko mengalami nyeri dada atau serangan jantung dan seperti pada pasien dengan riwayat penyakit hipertensi, diabetes melitus, kolestrol, strok bahwa semakin cepat mendapatkan pelayanan kesehatan akan semakin baik sehingga 
jika terdapat tanda gejala nyeri dada pasien dapat langsung mengenali, mengatasi kegawatan di rumah dan cepat mencari pelayanan kesehatan.

\section{DAFTAR PUSTAKA}

Adib-Hajbaghery, M., \& Hoseinian, M. (2014). Knowledge, attitude and practice toward complementary and traditional medicine among Kashan health care staff, 2012. Complementary Therapies in Medicine, 22(1), 126-132. https://doi.org/10.1016/j. ctim.2013.11.009

Fares, S., Irfan, F. B., Corder, R. F., Al Marzouqi, M. A., Al Zaabi, A. H., Idrees, M. M., \& Abbo, M. (2014). Emergency medicine in the United Arab Emirates. International Journal of Emergency Medicine, 7(1). https://doi.org/10.1186/1865-1380-7-4

Fares, S., Zubaid, M., Al-Mahmeed, W., Ciottone, G., Sayah, A., Al Suwaidi, J., Amin, H., Al-Atawna, F., Ridha, M., Sulaiman, K., \& Alsheikh-Ali, A. A. (2011). Utilization of emergency medical services by patients with acute coronary syndromes in the Arab Gulf States. Journal of Emergency Medicine, 41(3), 310-316. https://doi. org/10.1016/j.jemermed.2010.05.002

Farshidi, H., Rahimi, S., Abdi, A., Salehi, S., \& Madani, A. (2013). Factors associated with pre-hospital delay in patients with acute myocardial infarction. Iranian Red Crescent Medical Journal, 15(4), 312316. https://doi.org/10.5812/ircmj. 2367

Irman, O., Poeranto, S., \& Suharsono, T. (2017a). The Correlation Of Health Seeking Behavior And Transportation Mode With Prehospital Delay Time In Patients With Acute Coronary Syndrome At Emergency Department Of Regional Public Hospital Of Dr. T.C. Hillers. NurseLine Journal, 2(2), 87. https://doi.org/10.19184/nlj. v2i2.5922
Irman, O., Poeranto, S., \& Suharsono, T. (2017b). THE CORRELATION OF HEALTH SEEKING BEHAVIOR AND TRANSPORTATION MODE WITH PREHOSPITAL DELAY TIME IN PATIENTS WITH ACUTE CORONARY SYNDROME AT EMERGENCY DEPARTMENT OF REGIONAL PUBLIC HOSPITAL OF dr. T.C. HILLERS. NurseLine Journal, 2(2), 87. https://doi.org/10.19184/nlj.v2i2.5922

Liu, M. B. (2014). Cardiovascular diseases. In Chinese Medical Journal (Vol. 127, pp. 6-7). https://www.who.int/newsroom/fact-sheets/detail/cardiovasculardiseases-(cvds)

McSweeney, J. C., Lefler, L. L., Fischer, E. P., Naylor, A. J., \& Evans, L. K. (2017). Women's Prehospital Delay Associated With Myocardial Infarction. Journal of Cardiovascular Nursing, 22(4), 279-285. https://doi.org/10.1097/01. JCN.0000278958.98124.6e

Mooney, M. T. (2014). The ACS ResponseTime Intervention Trial: A Radomised Controlled Trial to Determine Whether an Individualised Educational Intervention Affects Response-time in Patients who Have Symptoms of Acute Coronary Syndrome (Doctoral dissertation, Trinity College D. https://scholar.google.co.id/ scholar?hl=id\&as_sdt $=0,5 \& \mathrm{q}=$ Mooney, + M.T.+2014.+A+Randomised +Controlled + Trial + to + Determine + Whether + an + Indi vidualised + Educational + Intervention $+\mathrm{A}$ ffects + Response-Time + in + Patients + who + have + Symptoms + of + Acute + Coronary + Syndrome. $+\mathrm{A}+$ thes

Notoatmodjo, S. (2005). Promosi Kesehatan Teori dan Aplikasi (cetakan 1). PT. Rineka CIpta. http://ucs.sulsellib.net// index.php? $\mathrm{p}=$ show_detail\&id $=88400$ 
O’Gara, P. T., Kushner, F. G., Ascheim, D. D., Casey, D. E., Chung, M. K., De Lemos, J. A., Ettinger, S. M., Fang, J. C., Fesmire, F. M., Franklin, B. A., Granger, C. B., Krumholz, H. M., Linderbaum, J. A., Morrow, D. A., Newby, L. K., Ornato, J. P., Ou, N., Radford, M. J., Tamis-Holland, J. E., ... Zhao, D. X. (2013). 2013 ACCF/ AHA guideline for the management of stelevation myocardial infarction: A report of the American college of cardiology foundation/american heart association task force on practice guidelines. Journal of the American College of Cardiology, 61(4), e78-e140. https://doi. org/10.1016/j.jacc.2012.11.019

Pitt, E., \& Pusponegoro, A. (2015). Prehospital care in Indonesia. Emergency Medicine Journal, 22(2), 144-147. https://doi. org/10.1136/emj.2015.007757

Saberi, F., Adib-Hajbaghery, M., \& Zohrehea, J.
(2014). Predictors of Prehospital Delay in Patients With Acute Myocardial Infarction in Kashan City. Nursing and Midwifery Studies, 3(4). https://doi. org/10.17795/nmsjournal24238

Suharyono, \& Amien, M. (2013). Pengantar Filsafat Geografi. Ombak. https://www. onesearch.id/Record/IOS3318.INLIS000 000000001150\#description

Taghaddosi, M., Dianati, M., Fath Gharib Bidgoli, J., \& Bahonaran, J. (2010). Delay and its related factors in seeking treatment in patients with acute myocardial infarction. ARYA Atherosclerosis, 6(1), 35-41. http://www.ncbi.nlm.nih.gov/ pubmed/22577411

Widyarani, L. (2014). Faktor yang Berperan sebagai Prediktor Mortalitas pada Pasien Non-ST Elevation Myocardial Infarction (NSTEMI) selama Hospitalisasi di RSUD dr. Soedono Madiun. 
